\title{
Study on Thyroid Hormone Status in Case of Female Infertility
}

\author{
*N Tasnim ${ }^{1}, \mathrm{R}$ Begum ${ }^{2}$
}

\begin{abstract}
Background: Infertility is a global health issue causing great personal sufferings and distress. It is also matter of social injustice and inequality. Both hyperthyroidism and hypothyroidism causes menstrual disturbances secondary to anovulation. The degree of disturbances varies from abnormal sexual development through menstrual irregularity to infertility.

Objective: To assess thyroid hormone status in female infertility.

Method: A cross-sectional study was carried out in the Department of Physiology, Dhaka Medical College, Dhaka during the period of July 2010 to June 2011. A total number of 250 female were included within the age limit of 20-40 years. Among them 125 subjects, healthy parous women were considered as control (group A) and 125 subjects, infertile women were considered as case (group B). The subjects were selected from Dhaka Medical College Hospital, infertility centre of BSMMU and BIRDEM, Dhaka. Data were collected in predesigned structured questionnaire form after taking consent. The study parameters are serum $\mathrm{T}_{3}, \mathrm{~T}_{4}$ were measured in the Department of Nuclear Medicine, DMCH, Dhaka. For comparison between two groups, statistical analysis were done by Student's unpaired't' test. $\mathrm{P}<0.05$ was considered as level of significance.
\end{abstract}

Results: Serum $\mathrm{T}_{3}$ and $\mathrm{T}_{4}$ were significantly lower in group $\mathrm{B}$ than that of group $\mathrm{A}(\mathrm{P}<0.001)$.

Conclusion: From the results of the present study, it may be concluded that lower level of serum $\mathrm{T}_{3}, \mathrm{~T}_{4}$ may be related with infertility.

Key Words: Infertility, Thyroid Hormones $\left(\mathrm{T}_{3}, \mathrm{~T}_{4}\right)$

\section{Introduction}

Infertility is a global health issue affecting $8-10 \%$ couples worldwide. It is not merely a health problems, it is also a matter of social injustice and inequality ${ }^{1}$.

Strictly defined, infertility means not being able to get pregnant after one year of unprotected coitus, or six months, if a woman is 35 years of age or older. Women

who can get pregnant but are unable to stay pregnant may also be infertile. Using this definition, approximately $14 \%$ of couples have not conceived in the first 12 months. At 24 months $4 \%$ and at 36 months only $1.9 \%$ of original group have not conceived $^{1}$. Estimation of overall primary and secondary infertility in South Asia on the basis of women at the end of their reproductive lives in the age group of 45-49years, suggests an infertility rate approximately 10\% : 8\% in India, 10\% in Pakistan, $11 \%$ in SriLanka, $12 \%$ in Nepal and $15 \%$ in Bangladesh ${ }^{2}$. Infertility affects approximately 1.3 million women in the world ${ }^{1}$. Thyroid function is important to maintain normal reproduction. Due to hyper and hypothyroidism there are changes in sex hormone binding globulin (SHBG) and sex steroids. As a result, thyroid dysfunction is associated with reduced fertility ${ }^{3}$. Normal function of thyroid hormone is necessary for conception and continuation of pregnancy 4 , 5 .

\footnotetext{
${ }^{1}$ Dr. Nusrat Tasnim, Assistant Professor, Department of Physiology, ShahabUddin Medical College, Dhaka

${ }^{2}$ Prof. Rokeya Begum and Head of the Department of Physiology, Anwar Khan Mordern Medical College, Dhaka

*Corresponding Author
}

Date of submission: 10.08.2016, Date of acceptance: 15.01.2017 


\section{Objectives}

\section{General Objective}

- To assess the thyroid hormone status in infertile women.

\section{Specific Objectives}

The specific objectives of the study

- To measure serum total $\mathrm{T}_{3}$ and total $\mathrm{T}_{4}$ in infertile women.

- To compare the thyroid hormone level between control and study group.

- To utilize the outcome of the study as background information for the clinician for better management of the patients.

- To create awareness among the clinician as well as patient about infertility.

\section{Methods}

The cross sectional study was done in the department of physiology, Dhaka Medical College, Dhaka from July 2010 to June 2011.

A total of 250 subjects were selected for the study. Among them:

Group A (control) was consist of 125 healthy parous women and

Group B (case) wasconsist of 125 infertile women.

Ethical clearance was taken from ethical review committee of Dhaka Medical College. Informed written consent was taken from the subjects. The study subjects were selected from the Dhaka Medical College Hospital, infertility unit of BIRDEM and BSMMU, Dhaka and control subjects were selected by personal contact.

Infertile female patient between 20-40 years were included.

Subjects were excluded with age $<20$ years and $>$ 40 years, postmenopausal women, subjects using contraceptive pill,patients with history of systemic disease and those unwilling to give consent to participate in the study.

After selection of the subjects the purpose of the study was explained to each subject with a cordial attitude giving emphasis on the benefits they would obtain from the study. They were encouraged for their voluntary participation. They were also allowed to withdraw themselves as soon as they wish. Before taking blood an informed written consent was taken from each subject. Data was collected in predesigned data collection form. With all aseptic precautions 5 $\mathrm{ml}$ of venous blood was drawn from the antecubital vein by a disposable plastic syringe. Blood was allowed to clot and then centrifuged at a rate 3000 rpm and supernatant clear serum was separated. Serum was taken into an eppendrof tube and was preserved in refrigerator at $28^{\circ} \mathrm{C}$ in Department of nuclear Medicine, Dhaka Medical College Hospital, Dhaka for estimation of serum $\mathrm{T}_{3}, \mathrm{~T}_{4}$. Serum total Triiodothyronine $\left(\mathrm{T}_{3}\right)$ was measured by radioimmunoassay kit (PR) IMK- 422, HTA CO. LTD., Beijing, 102413. (Ref. Oppeenheimer, J.H.) Role of plasma proteins in the binding, distribution and metabolisrn of the thyroid hormones. New England Journal or Medicine, 1968, 278 1153-1162. Serum total thyroxine $\left(\mathrm{T}_{4}\right)$ was measured radioimmunoassay Kit (PR) IMK-419. BEIJING ATOM HIGHTECH CO., LTD Beijing, 102413.

Statistical analysis was performed by using statistical program SPSS (Statistical Program for Social Sciences) version- 12 . The results were expressed as Mean (SD). Comparison between two groups was done by students't' test (unpaired), Correlation was done by using Pearson's Correlation Test, $\mathrm{p}$ value $<0.05$ was taken as level of significance.

\section{Results}

\section{Serum $\mathbf{T}_{3}$ :}

Results were shown in Table-I and Fig-1. The mean (SD) serum $\mathrm{T}_{3}(\mathrm{nmol} / \mathrm{L})$ value in group $\mathrm{A}$ was $2.34+0.56$ and in group B was 2.09 0.55. Mean (SD) serum $\mathrm{T}_{3}$ level was significantly lower $(\mathrm{P}<0.0001)$ in group $\mathrm{B}$ than that of group A.

\section{Serum $\mathbf{T}_{\mathbf{4}}$ :}

Results were shown in Table-II and Fig-2. The mean (SD) serum $\mathrm{T}_{4}(\mathrm{nmol} / \mathrm{L})$ value in group $\mathrm{A}$ was 139.8323 .83 and in group B was 120.36 38.29. Mean (SD) serum $\mathrm{T}_{4}$ level was significantly lower $(\mathrm{P}<0.001)$ in group $\mathrm{B}$ that of group A. 
Table- I: Mean (SD) Serum $\mathrm{T}_{3}(\mathrm{nmol} / \mathrm{L})$ in Different Groups $(\mathrm{n}=250)$

\begin{tabular}{cccc}
\hline Groups & Groups & Mean SD (IU/L) \\
\hline A & A & 2.34 & 0.56 \\
B & B & 2.09 & 0.55 \\
\hline
\end{tabular}

Statistical Analysis

\begin{tabular}{cccc}
\hline Groups & T & Df & p value \\
\hline A vs B & 0.944 & 248 & $0.0001^{* * *}$ \\
\hline
\end{tabular}

Table- II:: Mean ( $\mathrm{SD})$ Serum $\mathrm{T}_{4}(\mathrm{nmol} / \mathrm{L})$ in Different Groups $(\mathrm{n}=250)$

\begin{tabular}{cccc}
\hline Groups & N & \multicolumn{2}{c}{ Mean SD } \\
\hline A & 125 & 139.83 & 23.83 \\
B & 125 & 120.36 & 38.29 \\
\hline
\end{tabular}

Statistical Analysis

\begin{tabular}{cccc}
\hline Groups & T & Df & Df \\
\hline A vs B & 4.851 & 248 & 248 \\
\hline
\end{tabular}

The results are expressed as Mean SD. Unpaired Student's ' $t$ ' test was preformed to compare between groups. The test of significance was calculated and $p$ values $<0.05$ was accepted as level of significance.

\begin{tabular}{lllc}
\hline Group A: Control (Fertile women) & $\mathrm{n}$ & $=$ & Number of subject \\
\hline Group B: Case (Infertile women) & df & $=$ & Degree freedom \\
& $* * *$ & $=$ & Significant at \\
& & & $\mathrm{p}<0.001$ \\
\hline
\end{tabular}

Fig: 1

Mean Serum $\mathrm{T}_{3}$ in different groups

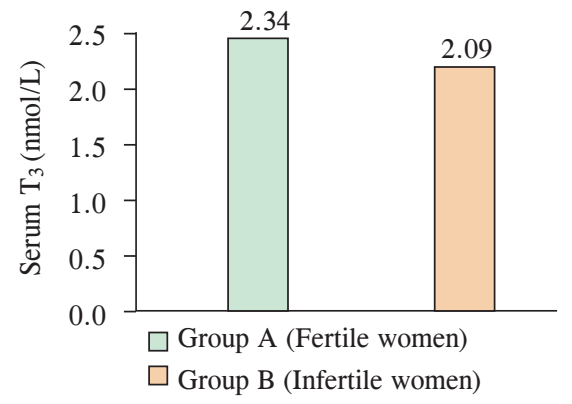

Fig: 2

Mean Serum $\mathrm{T}_{4}$ in different groups

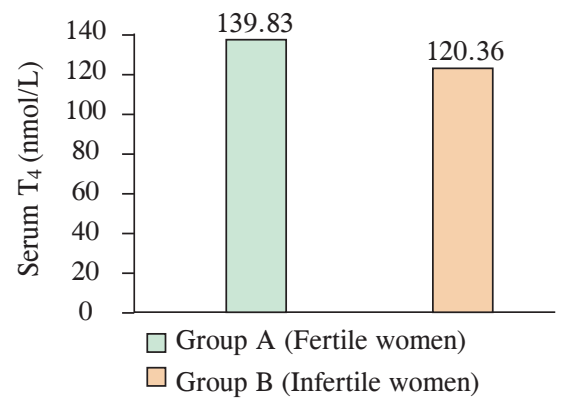

\section{Discussion}

In the present study the mean ( $\mathrm{SD}$ ) of $\mathrm{T}_{3}$ and $\mathrm{T}_{4}$ in infertile group is significantly lower $(\mathrm{P}<0.001)$ than that of control group.

The findings are similar with those reported in different studies, conducted by several researchers $1,2,6,7$. They suggested that thyroid hormones $\left(\mathrm{T}_{3}, \mathrm{~T}_{4}\right)$ stimulates the synthesis of sex hormone binding globulin (SHBG). When serum $\mathrm{T}_{3}$ and $\mathrm{T}_{4}$ level are reduced, the metabolic clearance rate of both testosterone and oestradiol is increased because of decreased binding to SHBG. In addition there are significant alternations in the metabolism of oestradiol in favour of oestriol. Some patients with decreased level of serum $\mathrm{T}_{3}$ and $\mathrm{T}_{4}$ also may have Galatorrhoea with or without raised concentration of prolactin.

Some research reports showed the significantly lower $\mathrm{T}_{3}$ and $\mathrm{T}_{4}$ in infertile women. They reported that thyroid hormones have direct effects on granulosa cells, luteal cells and oocyte maturation. Granulosa cells have nuclear binding sites with similar characteristic to $T_{3}$ receptors $8,9,10$.

Another research reports showed lower $\mathrm{T}_{3}$ and $\mathrm{T}_{4}$ in infertile women. These findings are similar to that of present study. They suggested that thyroid hormone enhance the action of follicle stimulating hormone (FSH) on aromatize activity and $\mathrm{T}_{4}$ act synergistically with gonadotropins to enhance luteinization, progestin secretion and luteinizing hormone receptors ${ }^{11,12}$. 


\section{Conclusion}

The present study revealed that the relative risk of female infertility significantly increased in hypothyroid women. So systematic screening of thyroid hormone should be considered in all women with female cause of infertility.

\section{Conflict of interest: none}

\section{References}

1. Abalovich M, Mitelberg L, Allami C, Gutierrez S, Alcaraz G, Otero $P$ and Levalle $O$, Subclinical hypothyroidism and thyroid autoimmunity in women with infertility; Gynecol Endocrinol, 2007; 23: 279-283.

2. Arojoki M, Jokimaa V, Juuti A, Koshinen P, Irjala $\mathrm{K}$ and Anttila, Hypothyroidism among infertile women in Finland; Gynaecol and Endocrinol, 2000; 14: 127-131

3. Grassi G, Balsamo A, Ansaidi C, Balbo A, Massobria $\mathrm{M}$ and Benedette $\mathrm{C}$, Thyroid autoimmunity and infertility, Gynaecol and Endocrinol, 2001; 15: 389-396

4. Krassas GE, Perros P and Kaprara A, Thyroid autoimmunity, infertility and miscarriage, Expert Rev Endocrinol Metab, 2008; 3: 127136

5. Poppe K, Glinoer D, Thyroid autoimmunity and hypothyroidism before and during pregnancy, Human reproduction update, 2003; 9: 149-161
6. Poppe K, GlinoerD, VanSteirteghemA, TournayeH, DevroeyP, Schiettecatte J and VelkeneirsB, Thyroid dysfunction and autoimmunity in infertile women, Thyroid, 2002; 12: 997-1001

7. Stray Pederson B and Stray Pederson S, Etiologic factors and subsequent reproduction performance in 195 couples with a prior history of habitual abortion, Am. J. Obstet. Gynecol, 1984; 148: 140-146

8. Gerhard I, Becker T, Eggert-Kruse W, Kling K, Runnebaum B, Thyroid and ovarian function in infertile womwn, Hum Reprod,1991, 6; 338-345

9. Wang C, Carpo LM, The epidemiology of thyroid disease and implicatios for screening, Endocrinol Metab Clin North Am, 1997, 26: 189-218

10. Wakim AN, Palijug WR, Jasnosa KM, Thyroid hormone receptor messenger ribonucleic acid in human granulose and ovarian stromal cells. Fertil Steril, 1994; 62: 531-4

11. Channing CP, TsaiV, SachsD, Role of insulin, thyroxine and cortisol in luteinization of porcine granulosa cells grown in chemically defined media, Bio Reprod, 1976; 15: 235-40

12. Bohnet HG, Fiedler $\mathrm{K}$ Leidenberger FA, Subclinical hypothyroidism and infertility [Letter]. Lancet, 1981; 2: 1278 